\title{
Incentive-Based Policy Design for Pollution Control and Biodiversity Conservation: A Review
}

\author{
Frans P. de Vries $^{1}$. Nick Hanley ${ }^{2}$
}

Accepted: 31 December 2015 / Published online: 27 February 2016

(C) The Author(s) 2016. This article is published with open access at Springerlink.com

\begin{abstract}
This paper provides a succinct review of the main developments in the literature on incentive-based policy mechanisms in the contexts of pollution control and biodiversity conservation, dating from the early beginnings of the science in the 1960s. A focal point in the review is on the design features of these policy mechanisms. Key developments in policy design were originally established in controlling externalities arising from pollution and have since been extended to policy design tailored towards biodiversity conservation. Special emphasis is given to the spatial characteristics of the environmental problems underlying both pollution control and biodiversity conservation. The paper concludes by drawing some lessons and setting out elements of a future research agenda in both policy domains.
\end{abstract}

Keywords Environmental policy instruments · Environmental markets · Mechanism design $\cdot$ Spatial coordination $\cdot$ Conservation auctions

JEL Classification D44 - D82 - Q57 · Q58

\section{Introduction}

Incentive-based policy instruments have long been argued by economists to be a more efficient means of achieving environmental goals such as reductions in polluting emissions and fostering the delivery of ecosystem services (Hanley et al. 2006). Over the last 25 years, governments world-wide have begun to make increasing use of policy instruments such as

Frans P. de Vries

f.p.devries@stir.ac.uk

Nick Hanley

ndh3@st-andrews.ac.uk

1 Division of Economics, University of Stirling Management School, Stirling FK9 4LA, Scotland, UK

2 Department of Geography and Sustainable Development, School of Geography and Geosciences, University of St. Andrews, St Andrews KY16 9AL, Scotland, UK 
"green" taxes and tradable pollution permits in an attempt to achieve environmental targets in a more cost-effective manner. One high-profile example is the European Union's Emissions Trading System (EU ETS) for carbon emissions. Another is the recently-ended programme of $\mathrm{SO}_{2}$ credit trading in the U.S. The use of incentive-based policy mechanisms has also increasingly found its way into policy-making in the area of biodiversity conservation and ecosystem services delivery. For instance, so-called "payments for ecosystem service" (PES) schemes have been promoted in the EU 2020 Biodiversity Strategy and have also been implemented in many EU countries as part of a package of agri-environment schemes. However, applying incentive-based instruments to achieve an improved delivery of ecosystem services from private land (comprising much of Europe's forests and almost all of its agricultural areas) has proved difficult in many cases.

Dating from the millennium ecosystem assessment (MEA 2005), the concept of ecosystem services has dominated public and scientific discussion of the role of "nature" in supporting human well-being. Exercises such as TEEB (http://teebweb.org) and the UK NEA (http:// uknea.unep-wcmc.org/) have highlighted the types of ecosystem services which are produced by the functioning of ecosystems and the biodiversity which they contain; how these services enhance human well-being, and what their economic value of such benefits might be; and the factors which explain trends in ecosystem extent and condition over time. The supply of ecosystem services and biodiversity typically goes unrewarded by market forces owing to missing markets: private landowners usually receive no direct financial reward for enhancing or protecting biodiversity, owing to the non-rivalness and non-excludability of these benefits (Hanley et al. 2006). Indeed, protecting biodiversity typically comes at an opportunity cost to landowners-for example, if it requires forgoing profitable land conversion or intensification. Similar arguments hold for the supply of many ecosystem services. Given the many market failures which characterize the supply of ecosystem services and the conservation of biodiversity, scholars have investigated the properties of alternative designs of PES schemes to partly correct these market failures (e.g., OECD 2010a; Wünscher et al. 2008; Engel et al. 2008; Miteva et al. 2012).

However, the TEEB and UK NEA exercises reveal substantial gaps in our knowledge; not only over how to value changes in ecosystem services and biodiversity, but also on how to best design effective PES markets (Banerjee et al. 2013; Polasky et al. 2014). This paper attempts to shed some light on the main lessons we have learnt from the disciplinary perspective of environmental and resource economics. ${ }^{1}$ We review the key literature on how incentive-based environmental policy can be utilized to encourage the private provision of ecosystem services and biodiversity conservation. ${ }^{2}$ However, we will first present a bird's eye view of the main incentive-based mechanisms that have been developed in the context of pollution control, since this was the problem which first shaped economists thinking on the use of incentives to improve environmental performance in an optimal or a cost-effective manner. Once this account has been established, we aim at showing how such schemes have been "translated" for use in the context of biodiversity protection and conservation.

Given the succinct nature of this review, our paper does not aim to provide an exhaustive account of the historical tracks of incentive-based mechanisms in both these domains. However, by sketching the main policy developments over time in the domains of pollution control and biodiversity conservation, we aim to provide readers with an impression of the current status of the literature in order to draw a future research agenda. In Sect. 2 we will start by sketching the origins and main developments in incentive-based policy mechanism

1 For an earlier, albeit more comprehensive survey of the literature, see Cropper and Oates (1992).

2 See Jack et al. (2008) for an earlier paper reviewing the experience of incentive-based PES schemes. 
for pollution control. Here we will particularly discuss the main properties of (Pigouvian) taxes and tradeable pollution markets, and will try to establish and identify the current status of these mechanisms. This will serve as a stepping stone for the discussion of the main developments and implementation of incentive-based schemes in the context of biodiversity conservation in Sect. 3. As we will see, this academic discussion has mainly been centred around the use of payments for biodiversity protection, including the use of conservation auctions. Finally, in Sect. 4 we make some concluding comments and suggest some elements of a future research agenda.

\section{Incentive-Based Mechanisms for Pollution Control $^{3}$}

\subsection{Pollution Taxes}

The idea of a government introducing a tax or subsidy to correct for the presence of externalities is an old one in economics, dating to Pigou's Economics of Welfare in 1920 (Pearce 2002). Market failure as an explanation for environmental problems is even older in economics, originating in Marshall's discussion of market failure relating to fisheries (Gómez-Baggethun et al. 2010). Pigou suggested that governments should introduce a tax, now known as a Pigovian tax, as an optimal tax on a negative externality. He offered the example of air pollution in Manchester as a case where externalities of production were creating significant damage costs on society, and where such as tax could improve national well-being. However, there are massive practical and considerable theoretical problems in using such an optimal pollution tax (Baumol and Oates 1988).

The idea of bargaining solutions to externality problems, associated with Coase (1960), has long been held up as an alternative means of attaining the optimal level of pollution. However, this concept runs into difficulties as a practical proposition for environmental policy once multiple parties, cumulative pollutants, free riding and moral hazard are considered. This meant the field was open to a new and more practical way of pricing pollution.

In the early 1970s, not one but two practical solutions to the problem of pricing externalities were proposed. Baumol and Oates (1971) showed that an efficient outcome could be achieved by setting a per-unit tax on polluting emissions. As Baumol and Oates (1988) put it: "A tax rate set at a level that achieves the desired reduction in the total emission of pollutants will satisfy the necessary conditions for the minimisation of the programme's cost to society." All that was required for this to be so was for firms to be cost-minimisers, and for a regulator to be able to identify and then implement the correct tax rate, given its environmental target, Faced with having to pay a tax, $t$, on each unit of emissions, the cost-minimizing response for a firm is to move along its Marginal Abatement Cost (MAC) curve to the point where $t=$ MAC. If all firms do this, then marginal abatement costs are equalised across polluters, a necessary condition for achieving the pollution standard (target) at the lowest aggregate abatement cost. The tax rate $t$ is set equal to the shadow price of the emissions target, and is determined both by the severity of this target and the position of the aggregate MAC curve.

If regulators face uncertainty about these MAC functions, and thus about the correct tax rate, then they need to iterate onto the correct rate: setting a best-guess tax rate, and then revising this rate up or down dependent on the resultant level of emissions relative to the target (Baumol 1972). This iterative approach would also be needed where abatement costs are shifting over time, partly due to technological change, and partly due to changes in prices

3 Note that parts of this section draw extensively on chapter 5 of Hanley et al. (2006). 
of inputs and outputs. However, such an approach to tax setting could impose adjustment costs on firms (Walker and Storey 1977), and gives forward-looking firms an incentive to behave strategically, since future tax levels depend on current period emissions for all firms (Karp and Livernois 1994). Experimental studies have recently tried to establish the overall welfare effects of such dynamic tax models where the regulator is unsure about what tax rate to set (see, for example, Vossler et al. 2013).

The original work by Baumol and Oates described above relates to a "uniformly mixed pollutant", where damages depend only on aggregate emissions and not their spatial distribution. However, for many potentially polluting substances, ambient concentrations at a given monitoring point are dependent not just on the total amount of emissions but their spatial location too. Targets set for such pollution problems are likely to be in terms of some ambient measure of pollutant concentrations such as $\mathrm{NO}_{\mathrm{X}}$ and $\mathrm{PM}_{10}$. The implications for the Baumol and Oates theorem of a non-uniformly mixed pollutant are that a single tax rate will no longer be efficient, since the tax rate should vary across sources according to their marginal impacts on ambient air or water quality levels. Suppose that the ambient level of pollution at any monitoring point $j, a_{j}$, is a function of emissions from all sources: $a_{j}=\sum_{k} d_{j k} e_{k}$. The $d_{j k}$ coefficients are often referred to as "transfer coefficients" where there are $k=1, \ldots, K$ sources and $j=1, \ldots, J$ monitoring points. In the context of water quality, for example, the transfer coefficient $d_{j k}$ shows the impact of discharges from source $k$ on water quality at monitoring point $j$. For non-uniformly mixed pollutants, the regulatory agency's target might be specified as $\sum_{k} d_{j k} e_{k} \leq a_{j}^{*}$, where $a_{j}^{*}$ is the ambient target at monitoring point $j$. The regulator's problem is now to minimise aggregate abatement costs subject to this constraint. In order to achieve an efficient solution, each firm must face a different tax rate, which is determined by that firm's degradation of environmental quality at each monitoring point (given by the transfer coefficients), and by the ambient target itself, i.e., is equal to $\sum_{j} d_{j k} \mu_{j}$ for firm $j$. As Tietenberg (1974, p. 464) argued: "forcing upwind and downwind polluters to pay the same tax (can) produce the desired concentration (reduction), but at a cost which exceeds the minimum cost means of achieving that concentration." There are clear links between this finding and the ambient pollution trading idea, which we will discuss in more detail below.

Another complication relates to non-point source pollution. If nutrient run-off from farmland which pollutes waterways is too costly or just impossible to monitor at the farm (source) level, then one cannot tax actual emissions. One alternative is to tax the inputs (such as fertilizers), which contribute to this non-point source pollution. Common (1977) first showed that, so long as the "pollution production function" relating inputs to emissions is known, a desired reduction in emissions can be achieved at least cost by means of a tax on inputs. However, such pollution production functions may be partly stochastic, and may vary spatially and over time (Aftab et al. 2007). Input taxes may also involve problems when input substitution occurs if the substitute input has adverse environmental effects.

An alternative tax solution suggested in the literature for non-point source pollution is Segerson's (1988) ambient tax. This idea addresses the moral hazard aspect of this kind of pollution: if a farmer knows that his emissions cannot be monitored and if emissions reduction is costly, then there is an incentive to shirk on pollution control. The Segerson tax is composed of two components: a per unit tax or subsidy, which depends on the difference between actual ambient levels and the target, and a lump-sum penalty, which is imposed if emissions are too high so that the target is not reached (Hanley et al. 2006, chapter 4). Alternatively, the scheme can be set up as a situation where each firm faces a tax payment which is only positive if ambient pollution exceeds a threshold, and where the tax rate depends on the difference between ambient quality and this threshold (Suter and Vossler 2014). The 
threshold for triggering payments can be different from the target level of ambient quality. A large literature has since emerged on the conditions under which ambient taxes can achieve an efficient outcome. Part of this literature is addressed to the nature of the damage cost function, and to the extent of abatement options open to the farmer (Horan et al. 1998). Part of it relates to the beliefs of regulators and farmers about the relationship between farm-level land management and emissions, and ambient pollution levels (Cabe and Herriges 1992). Experimental tests of the consequence of the shape of the damage function, the nature of the ambient tax schedule and the degree to which farmers communicate with each other include Suter et al. (2008), who compare linear with non-linear tax schedules. Other approaches to applying pricing to non-point pollution include estimated emissions taxes, or subsidies for changes in land/livestock management or land use.

There are now many examples of Baumol and Oates-type pollution taxes in use in environmental policy world-wide. These include taxes on inputs, such as fertilizer, pesticide 4 and fuel taxes (the latter constituted the biggest single category by value of environmental taxes in the OECD in 2010); taxes on estimated emissions, such as $\mathrm{CO}_{2}$ taxes, and taxes on measured emissions, such as the Swedish $\mathrm{NO}_{\mathrm{X}}$ tax on combustion plants and the $\mathrm{NO}_{\mathrm{X}}$ tax in New South Wales, Australia (OECD 2010b). Within the European Union, environmental tax revenues are dominated by energy and transport taxes (e.g., on freight transport). Many countries also tax the disposal of solid wastes to landfill sites. What the European Environment Agency classifies as "environmental tax revenues" have risen slowly in real terms-by around 19\%-since 1995 (EEA 2014). However, no examples exist of the kinds of ambient damage-weighted schemes described above for non-uniformly mixed pollutants, or of Segerson-type ambient pollution tax schemes. This may possibly be due to the complexity of the former and the perceived unfairness of the latter, since the tax liability of individuals depends on the actions of others, and not just the pollution due to the actions of that individual.

\subsection{Tradeable Pollution Permits}

An alternative approach to pollution taxes as a way of achieving a target reduction in pollution at least cost is that of tradeable pollution permits (TPPs). This idea originated with Crocker (1966) and Dales (1968), whilst the original proof of the least-cost property of TPPs is due to Montgomery (1972). The main idea behind TPPs is to allocate emission rights and make them tradeable. This results in a market for the right to pollute and consequently in the emergence of a market price for this right. If the permit market is competitive and all possible gains from trade are realized, this market minimizes the resource costs of achieving a pollution abatement target. At the outset of the scheme, permits may be issued through grandfathering or auctioning. In either case, firms are then allowed to trade these permits. We expect firms with relatively high MACs to be buyers and firm with relatively low MACs to be sellers, assuming that the initial permit allocation is not cost minimizing. In equilibrium, each firm equates the permit price, $p^{*}$, with its MAC schedule. For a uniformly-mixed pollutant this is a necessary condition for individual cost-minimisation across all dischargers. These reactions by firms move them to their cost-minimising positions and imply differing emission levels (and emission reductions) across firms, just as with a Baumol and Oates tax.

Fowlie and Muller (2013) and Muller and Mendelsohn (2009) discuss the conceptual issues around how to design market-based regulation for non-uniformly mixed pollutants, and present contrasting empirical results on the net gains from trade with spatial differentiation. These gains from differentiation depend partly on the spatial variation in marginal damage

4 Denmark and Norway have levied environmental taxes on pesticides and fertilisers. 
costs. As these authors note, several alternatives to reflect spatial variations in marginal damage costs were proposed in the early literature. In an ambient permit system, permits are denominated in units of damage at receptors. There is a separate market in permits at each receptor, and firms must trade in as many markets as their emissions affect receptors. Transaction costs would therefore be relatively high. What is more, total emissions can rise as a result of trading, which may cause knock-on environmental problems such as an increase in the long-range transport of pollutants (Atkinson and Tietenberg 1987). Allowing for spatial variation in damages can move a permit market closer to the outcome where marginal costs per unit of damage reduction are equalised across sources, but at the expense of a potential increase in transactions costs and a fall in the volume of trading.

Using an optimisation model where the regulator seeks to minimise the sum of damage and abatement costs (rather than just trying to hit an arbitrary target), Fowlie and Muller (2013) show that the first-order condition for a socially-optimal allocation of abatement across sources can be expressed as: $c_{i}^{\prime}\left(e_{i}\right) / c_{j}^{\prime}\left(e_{j}\right)=\delta_{i} / \delta_{j}$, where $e_{i}$ and $e_{j}$ are emissions from firm $i$ and $j$, respectively, and $\delta_{i}$ and $\delta_{j}$ represent the marginal damages associated with one unit of emissions from each firm. Thus, in the permit market equilibrium, the ratio of marginal abatement costs must be equal to the ratio of damage costs across space. Each firm needs to hold enough permits to validate its emissions as weighted by its own marginal damage parameter relative to average damages. This outcome can be potentially achieved by declaring a matrix of trading ratios which show how many units of emissions reduction from a given source $i$ are equivalent to one unit of emissions from another source $j$, known as the "numeraire source" (Muller and Mendelsohn 2009). Muller and Mendelsohn show what these trading ratios look like for $\mathrm{SO}_{2}$ emissions from a selection of sources in the United States, and compare the net effects on welfare of introducing such spatial differentiation into permit trading ratios. However, despite recognition by the U.S. courts that many existing tradeable permit schemes fail to allow for spatially-varying damages, in practice few examples exist of water quality trading markets which use such trading ratios: salinity trading in the Hunter River basin, Australia, and phosphorus trading in the Minnesota River being two rare examples (Fisher-Vanden and Olmstead 2013).

Three other issues have emerged in the literature that are worth noting here. First, an important consideration is whether firms should be allowed to bank or borrow permits across periods. For instance, a firm could decide to abate more than was required in the present period, earn credits and then bank these for use in a future period, when perhaps it thought abatement costs or permit prices would be higher. Allowing the banking of permits has been argued to be desirable since it can even out spikes in permit markets due to sudden increases in the demand for an output such as electricity (Ellerman et al. 2003); can act as a hedge against uncertainty; and can encourage early reductions in emissions. Cason and Gangadharan (2006) found that prohibiting permit banking and borrowing in the laboratory resulted in much greater price instability, especially when external shocks (e.g., due to weather events) are correlated across firms. However, regulators may worry that banking will result in violations in environmental standards in some time periods. A possible explanation put forward by Cason and Gangadharan (2006) for this non-compliance is that firms may perceive that benefits can be reaped from under-reporting emissions, so that unused permits can be utilized in future periods.

A second design issue relates to the possibility of allowing trade between point and non-point sources of pollution. For instance, both point sources (such as industrial plants and sewage treatment works) and non-point agricultural run-off are responsible for severe oxygen depletion in the northern Gulf of Mexico (Ribaudo et al. 2005). Allowing trades between these two source types allows for cost-savings in pollution control, since marginal abatement 
costs for point sources were found to be typically greater than marginal abatement costs for non-point sources. Simulations showed that a net welfare gain of $\$ 46$ billion was possible with such trading. However, designing a point-nonpoint pollution trading scheme is complex (Shortle and Horan 2008; Stephenson and Shabman 2011).

A third issue is that of whether and how to establish a price floor in a permit market, that is a minimum value below which the market price is not allowed to drop. A recent criticism of the EU ETS has been that the carbon price has been too low (partly due to the economic downturn post-2008) to provide a sufficient incentive for firms to invest in low-carbon technologies (e.g., Burtraw et al. 2010). Price floors can also help to moderate uncertainty over future permit prices (e.g., Weber and Neuhoff 2010). Wood and Jotzo (2011) set out three mechanisms for establishing a price floor. First, the regulator can commit to buy permits once the price reaches a certain low level. Second, a reserve price can be used in permit auctions where sales are not made below this price. Third, a price floor can be established by an additional carbon tax operating alongside a permit trading scheme. Price ceilings could also be implemented, if there are fears that permit prices could be "too high".

Related to this is the problem of permit price volatility. A reserve auction can be used as an alternative mechanism to a price floor to reduce volatility: the regulator keeps back part of the total permit supply and then auctions this during periods of tight demand (e.g., Murray et al. 2009). Price collars, which set a moving ceiling and floor around the current period permit price have also been proposed as a means of mitigating price volatility, with the regulator stepping into the market to increase or decrease the supply to influence the price, or to pay subsidies or impose taxes in addition to the permit scheme. Perkis et al. (this issue) study price controls in the laboratory, in particular hard and soft price ceilings. Whilst a hard ceiling does not allow the permit price to rise above an absolute maximum level, a soft price ceiling is similar to the reserve auction with a minimum reserve price for permits (see also Fell et al. 2012). Perkis et al's study shows that hard ceilings are more effective in controlling permit price fluctuations relative to soft price ceilings, in particular in the case of a reserve auction with a price floor. From a permit market design perspective the results indicate that hard ceilings would be the preferred mechanism in view of controlling permit prices. Furthermore, recent evidence from a laboratory experiment by Stranlund et al. (2014) suggests that complementing price controls with permit banking can reinforce price stability in a market environment where permit price fluctuations are driven by abatement cost uncertainty.

As noted above, tradeable permit markets have become increasingly common for the control of air pollution in both the U.S. and the EU, but also for the management of some water quality problems in Australia. Efficient permit market design is much simpler for $\mathrm{CO}_{2}$ than is the case for non-uniformly mixed pollutants such as $\mathrm{SO}_{2}$ and $\mathrm{NO}_{\mathrm{X}}$, since for uniformly mixed pollutants policy designers do not need to worry about the spatial location of discharges (aside from cases of pollution leakage, where emissions move outside the political zone of effective control). This may explain the recent surge in carbon trading schemes (e.g., in California), which has occurred despite claims by some economists that carbon taxes are a better option (e.g., Goulder and Schein 2013). For water pollution, success with permit trading has been much more limited. The smaller number of potential traders in any catchment as well as the high spatial dependence of damage costs for most water pollution problems may be important factors here..$^{5}$

5 See Jones and Vossler (2014) for a laboratory study analysing institutional design features of water quality credit trading markets. 


\section{Incentive-Based Mechanisms for Biodiversity Conservation}

Conservation efforts are often targeted at private landowners, since many valuable ecosystem services and biodiversity is found on privately-owned land. However, increasing the supply of ecosystem services and biodiversity typically comes at a cost to these private landowners; for example, in deciding to protect a wetland rather than convert it to pasture, or in fencing natural vegetation to protect it from grazing. On the other hand, governments-often the buyers of biodiversity and/or ecosystem services - typically face uncertainty as to how these costs are distributed across landowners. Moreover, it is difficult and costly for the buyer to monitor the actions of landowners if they are offered contracts for undertaking certain land management actions thought to benefit the environment, such as biodiversity enhancement, water quality improvement and reduction of eutrophication (nutrient pollution).

In addition to cost heterogeneity, environmental benefits can also vary spatially across land. The heterogeneous nature of both cost and benefits of land use, and the existence of information asymmetries between regulators and landowners, makes it difficult for policymakers to maximise the net environmental benefits to be delivered by scarce public funds (Hajkowicz et al. 2007), due to problems of adverse selection and moral hazard (Ferraro 2008; Fraser 2009; White and Sadler 2012).

This setting poses formidable challenges to the design of policy mechanisms in being both effective and efficient in delivering environmental benefits. Economists have become increasingly interested in how to incentivize private landowners to change their behaviour in order to increase the supply of environmental goods and ecosystem services (see Engel et al. 2008). Throughout the European Union, agri-environmental PES schemes have involved the voluntary opt-in of farmers, who, in return for undertaking a range of management actions, receive fixed payments on a per-hectare basis for land enrolled (Hanley et al. 2012). However, the inherent problem underlying such uniform payment schemes is adverse selection, implying that payment levels might not relate to the actual costs of participation for individual landowners, who are over-compensated for their participation due to a lack of information on the part of the regulatory agency regarding the opportunity costs of participation. Moreover, uniform payment schemes may also not enroll those farmers or landowners who can deliver the greatest environmental benefits.

The challenge of revealing landowners' real opportunity costs, in conjunction with attempts to find ways to increase the environmental benefits delivered by participation, has resulted in significant advances in the area of policy design in the last two decades. As mentioned before, maximizing environmental benefits whilst at the same time enhancing participation of farmers given the inherent differences in their opportunity costs is key in view of constrained public funds. An important incentive-based mechanism that can potentially deal with this problem is the conservation auction. Seminal work by Latacz-Lohmann and Van der Hamsvoort $(1997,1998)$ showed that auctions can potentially deal with the issues of adverse selection and lack of cost-effectiveness by promoting price competition amongst landowners for the supply of non-marketed goods. In conservation auctions, landowners tender bids to a regulatory agency (or some other buyer such as a conservation organization or water company) indicating their minimum willingness to accept compensation for undertaking specified conservation actions. The regulatory agency offers conservation contracts to those bidders whose asking price - weighted by the expected environmental benefits of their actions - is most cost-effective first, taking on higher and higher bidders up to some budget constraint or environmental target. Competition with other bidders gives landowners an incentive to moderate their bids, although the fact that the (opportunity) cost of the 
environmental action is unobservable to the government allows landowners to still earn an information rent (Rolfe and Windle 2011).

Cason and Gangadharan (2004) test-bed the basic conservation auction in the laboratory. In one of the treatments they vary the auction's information structure by revealing the potential benefits of conservation projects to sellers (landowners). Interestingly, relative to a treatment without providing this information, the overall performance of the auction decreases under the "full" information treatment. The authors argue that this is due to sellers' less accurate representation of the opportunity costs for projects exhibiting high benefits. ${ }^{6}$ The finding that information concealment about potential conservation benefits can lead to more efficient auction performance has recently also been confirmed theoretically by Glebe (2013). Glebe's study also demonstrates that revealing such information may attract landholders and can thus lead to higher participation rates in the auction, hence making the market "thicker", an issue to which we will come back later.

Cason and Gangadharan (2004) further show that the pricing rule matters for auction performance, by comparing a uniform price auction with a discriminatory price auction where successful sellers are paid a contract sum equal to their bid. Their experiment reveals that a conservation auction based on a uniform pricing rule results in some sellers being over-compensated relative to their actual opportunity costs. This result is similar in spirit to the aforementioned inefficiency resulting from a fixed-rate payment scheme (e.g., on a per-hectare basis) as applied in many EU agri-environment schemes. As a result, overall auction performance is improved with a discriminatory pricing rule where the actual price is offered to individual successful sellers. A similar experimental finding is derived in Cason and Gangadharan (2005) where a uniform price auction is compared with a discriminatory price auction in a context of non-point source pollution. In their experiment a discriminatory auction tends to deliver reductions in non-point source pollution problems more efficiently than a uniform price auction. ${ }^{7}$

Schilizzi and Latacz-Lohman (2007) extend this work by testing experimentally how a discriminatory price conservation auction compares with an equivalent fixed-rate payment mechanism through the lens of cost-effectiveness, information rents, and economic efficiency. They do so by distinguishing two auction formats: a budget-constrained auction and a targetconstrained auction. In the former auction type the budget is fixed and given but the target (outcome) uncertain; in the target-constrained auction the outcome is predetermined but subject to cost uncertainty. In a static (one-period) market setting the experimental evidence indicates that both auction formats are superior to the fixed-rate payment scheme in terms of overall performance. However, in a dynamic setting the auction's dominance over the fixedrate scheme reduces. This means that when sellers have the opportunity to learn from past decisions and can update their bidding behavior, fixed-rate payment schemes can perform as well as an auction mechanism.

More recent experimental analyses by Arnold et al. (2013) on budget-constrained discriminatory auctions for conservation reveal that this mechanism may not be able attract the full set of potential bidders (landowners), implying that auctions can actually induce adverse

6 See Cason et al. (2003) for a more detailed description of the experimental design in the context of non-point source pollution resulting from agricultural land management, such as fertiliser run-off from fields.

7 Note that this research does not take into account compliance monitoring. In reality monitoring compliance in agri-environment schemes is often imperfect, resulting in reduced incentives for (some) landholders to comply with land management changes. This can undermine the delivery of conservation benefits and could lead to reduced cost-effectiveness of the auction mechanism. In an experimental study, Kawasaki et al. (2012) find evidence indicating that, in situations where monitoring landholder compliance is imperfect, the uniform price auction results in overall greater efficiency than the discriminatory price auction. 
selection. This, in turn, can undermine the potential supply of ecosystem services and biodiversity from land. Contrasting the auction institution with screening contracts, they further show by means of laboratory experiments that such contracts may outperform auctions in terms of social welfare. However, in a dynamic auction experiments where bidders can enter and submit offers in any period, Fooks et al. (2015) show that such auction institutions are more efficient relative to a no-auction baseline. This result could imply that dynamic conservation auctions with endogenous entry may result in "bidder selection" over time and induce bidders to sort themselves into different types. In this respect, allowing for endogenous entry seems to be an interesting design feature which is of relevance for real markets, as this could potentially mitigate the adverse selection problem identified by Arnold et al. (2013).

Although competition amongst bidders in conservation auctions can lead to improved costeffectiveness, Rolfe et al. (2009) present results from a conservation auction implemented in an Australian field experiment to study how extending the usual single round auction to a multiple bidding round auction affects performance. Their study shows that such an extension allows landowners to learn and obtain more information during the auction. This is conducive to reducing overall strategic uncertainty, which subsequently leads to a more efficient outcome. An iterated (multi-round) conservation auction has also been studied by Reeson et al. (2011), but with the additional design feature of a variable, unknown end period of the auction. This revealed two results. The first is that, over time, bidders can observe the location of the other bidders in the landscape. The ability to "observe" bids reduces uncertainty, which is conducive to steering spatial coordination of land management actions. Secondly, not knowing when the auction ends reduces rent seeking behaviour as it encourages subjects to bid more modestly in earlier rounds given subjects will not be able to revise bids downward from an initial high bid once the auction has ended. Although the study by Reeson et al. (2011) shows that coordination of landowner behaviour can be "steered" in the laboratory, these kinds of auctions are still relatively rare in practice. Actual conservation auction schemes have generally placed relatively little focus on the spatial coordination of landowner participation in order to improve delivery of biodiversity and ecosystem services across land. This is because implementing auctions with explicit spatial coordination is challenging.

Considerable experience in designing and implementing conservation auctions now exists in Australia, and analysis shows that facilitating sufficiently high levels of participation is crucial to scheme performance, as is the design of the environmental metric used to weight bids (Williams et al. 2012). Key features impacting on participation included length of contract, complexity of legal agreements, payment schedule, monitoring requirements and communication with potential bidders (Whitten et al. 2013).

An alternative price-based policy instrument that accounts for the dependency between conservation benefits and spatial connectivity of land parcels is the agglomeration bonus (Parkhurst et al. 2002; Parkhurst and Shogren 2007). This scheme offers additional payment to landowners who voluntarily enroll parcels of land which lie next to neighbours' land which is also offered for enrolment. Parkhurst et al. (2002) show that this mechanism inherently features multiple Nash equilibria which can ranked in terms of the amount of habitat protected, the expected returns to landowners, and net social benefits. Test-bedding the agglomeration bonus in the laboratory, the authors find that habitat fragmentation can significantly be reduced relative to a no-bonus benchmark. Indeed, the experimental results show that subjects were often able to coordinate on the efficient (contiguous) land reserve. Parkhurst and Shogren (2007) subsequently incorporate a more explicit spatial target into the basic agglomeration bonus scheme. Laboratory evidence indicates that the agglomeration bonus is still able to foster coordination of land management actions but can be more effective depending on the 
type of land reserve targeted (for instance, a corridor style habitat or a single core habitat style).

Banerjee et al. (2012) extend this seminal work by examining how spatial coordination is fostered under an agglomeration bonus schemes by varying the group size of subjects (who act as landowners) in a laboratory experiment. They implement a simple (fixed) circular network structure but as main treatment vary the size of the network (i.e., different number of farms in the neighbourhood) in order to test its impact on spatial coordination of landowners and the scheme's effectiveness in generating environmental benefits. The experiment indicates a significant difference in patterns of coordination between groups. In particular, coordinating land management actions is more difficult in the larger network compared to the smaller network. Using a similar kind of network structure but without varying the network size, Banerjee et al. (2014) also identify multiple Nash equilibria in the experimental agglomeration bonus scheme, which can lead to coordination failure by not reaching the socially optimal land configuration. However, they show that the information structure available to landholders has implications for the success of the scheme in delivering environmental benefits in that revealing the land management choices of a subject's direct and indirect neighbours enhances the ability to coordinate to the Pareto dominant equilibrium. The policy message is clear: fostering market transparency by revealing landowners' land management actions is likely to improve the environmental outcome in terms of higher conservation benefits generated from spatial connectivity and spatial spillovers.

Whilst this research on the agglomeration bonus mechanism is a promising start, current limitations include the treatment of heterogeneity in landowner and environmental characteristics, and the assumption of common knowledge of payoffs. Perhaps most importantly, the current understanding of the agglomeration bonus does not deal with the adverse selection or (cost) in-efficiency problems since no auction mechanism is used to decide participation. Given this limited degree of landholder participation, these markets can be relatively "thin". A novel incentive mechanism developed by Parkhurst et al. (this issue) to simultaneously address the issue of landholder heterogeneity and to create a thicker market for habitat conservation is called Tradable Set Aside Requirements (TSARs). It builds on the concept of tradeable development rights (habitat/conservation banking), similar in spirit as a market for tradeable pollution permits as discussed in the previous section. The main difference with an agglomeration bonus is that TSARs create an explicit market environment where buyers and sellers can trade conservation. Parkhurst et al. test-bed the TSARs mechanism both with and without an agglomeration bonus. The experimental results overall reveal that TSARs are generally effective in improving the spatial connectivity of habitat. However, when combining TSARs with an agglomeration bonus, the experimental results reveal a trade-off. While on the one hand the environmental effectiveness increases due to enhanced habitat connectivity, the costs are higher compared to the treatment with a TSARs mechanism only.

Two important features highlighted in the aforementioned policy mechanisms is the desirability to foster spatial coordination and allowing for competition between potential suppliers. Yet jointly achieving these objectives is difficult due to a tension between information provision, cooperation and competition. One way forward is to explore spatially-differentiated conservation auctions. However, to enhance environmental outcomes by fostering the contiguity of landholdings, cooperation rather than competition between landowners would likely be much more effective, since cooperation between neighbouring landowners directly increases spatial coordination (Windle et al. 2009). So far the existing literature on conservation auctions typically assumes that bids from landowners are independent. That is, the current generation of conservation auctions do not address the issue of spatial coordination and do not incorporate the potential synergies across landowners. However, recently Banerjee 
et al. (2015) built spatially adjacent land use management into a conservation auction and tested it in the laboratory as to how information about the regulator's spatial objective impact on subjects' bidding behavior and subsequent auction performance. Interestingly, although disclosing information about the spatial features increases rent seeking among participants, the auction's overall efficiency is unaffected.

\section{Conclusion and Directions for Future Research}

This paper has provided a brief overview of the main economic incentives which have been developed to reduce pollution, to increase the supply of desirable ecosystem services and to enhance biodiversity conservation. Much of the early literature in pollution control economics focused on the problems of efficiently regulating point source emissions of local and regional air and water pollutants, which reflected the dominant environmental concerns of the 1970s. Increasingly, the focus of the literature has moved to non-point source pollution (which is now the main cause of low ecological quality in many European and U.S. water bodies) and to the design of pollution control instruments as part of climate change policies, with the fast growth of (regional) $\mathrm{CO}_{2}$ markets being particularly important. Price collapses and price volatility in the carbon market have also promoted recent work on improving the functioning of permit markets, along with developing a broader understanding of what motivates firms with regard to their environmental choices rather than the simple cost-minimisation strategies of the early literature. Finally, a literature is emerging on the optimal design of pollution taxes when options exist about how to define the tax base (emissions, inputs, outputs) and how much to differentiate taxes across sectors when administrative and abatement costs differ across sectors and policy choices (Shortle et al. 1998; Smulders and Vollebergh 2015). This involves a balancing of the gains and losses of greater complexity in policy design for pollution taxes, which has parallels in the Payment for Ecosystem Services (PES) literature with work by Armsworth et al. (2012).

Indeed, a large body of work now exists on how best to design PES schemes and incentives which assist in biodiversity conservation. Here, attention is rather on the interaction of one buyer (typically a government or conservation agency) with multiple potential sellers who can increase the supply of such environmental goods by changing how they manage land. One can think here of three main areas of research that still need further investigation.

The first relates to the use of conservation auctions. As has been clear since the late 1990s, auctions have the potential to achieve considerable gains in efficiency in achieving environmental goals such as restoring native vegetation or reducing non-point source pollution from farmland. A considerable degree of practical experience with implementing such auctions has now been attained, mainly in Australia and the United States. However, there are a number of design and implementation issues which require more thought. One is that of achieving spatial coordination in auctions (Windle et al. 2009), which implies the need for coordination amongst bidders (e.g., if group bids are rewarded). But this then raises a problem over how to deal with collusion amongst bidders, since this can lead to the erosion of cost savings over time. For instance, Calel (2012) studies how a joint bid of a group of landholders can be integrated into a conservation auction. Although he finds that coordination of landholder action is improved, auction efficiency is reduced. The second design issue relates to the level of design complexity and the transactions costs of auctions (increasing complexity can deter participation). Another design issue relates to bundling of ecosystem services and biodiversity conservation, whereby bidders offer multiple environmental goods for a single price. 
We are not aware of any existing conservation auctions with this feature. However, perhaps a worthwhile route to explore is to design auctions by drawing upon features of the Higher Level Stewardship scheme in the UK, where farmers have to offer multiple environmental improvements on their farm or land in return for a higher payment.

A second avenue of research which is needed relates to the design of conservation subsidies (as distinct from auctions). Some papers are starting to emerge on the properties of contracts which pay for environmental outcomes rather than management actions and for contracts which pay for a mix of actions and outcomes (Derissen and Quaas 2013; White and Hanley, this issue). Paying for environmental outcomes incentivises farmers to produce such outcomes more efficiently, exploits the private information they hold on species distributions and abundance on their land, and avoids the regulator having to monitor hard-to-observe inputs such as conservation effort. However, outcome-based payments transfer risk onto the farmer and imply costs for measuring environmental outcomes.

A third field of useful future research will lie in the closer integration of ecological modelling and ecological indicators with the design of PES-type incentives. Since the aim of such incentives is to increase the supply of environmental goods, understanding how this supply is related to changes in land use and land management is key. Examples include understanding the spatial variability in ecological response across species to changes in land management (Armsworth et al. 2012); or the ecosystem production function which generates economic benefits, an example being the interactions between wild and commercial pollinators with their ecosystems and with food crops (Ehmke et al. 2015). Environmental metric design has also been argued to be key to explaining the relative success or failure of conservation auctions (Williams et al. 2012), but little effort has been made so far in including the properties of environmental metrics in the optimal design of economic incentives for biodiversity conservation or ecosystem service supply.

Acknowledgments The research reported here is derived from work conducted under the Eco-Delivery project (http://www.eco-delivery.stir.ac.uk/). We are grateful to the European Investment Bank (EIB) for financial support through their EIB-University Research Action Programme (theme Financial and Economic Valuation of Environmental Impacts). The findings, interpretations and conclusions presented are entirely those of the authors and should not be attributed in any manner to the EIB. Any errors remain those of the authors. We thank an anonymous referee for helpful comments on an earlier version.

Open Access This article is distributed under the terms of the Creative Commons Attribution 4.0 International License (http://creativecommons.org/licenses/by/4.0/), which permits unrestricted use, distribution, and reproduction in any medium, provided you give appropriate credit to the original author(s) and the source, provide a link to the Creative Commons license, and indicate if changes were made.

\section{References}

Aftab A, Hanley N, Kampas A (2007) Co-ordinated environmental regulation: controlling non-point nitrate pollution while maintaining river flows. Environ Res Econ 38:573-593

Armsworth PR, Acs S, Dallimer M, Gaston KJ, Hanley N, Wilson P (2012) The cost of policy simplification in conservation incentive programmes. Ecol Lett 15:406-414

Arnold MA, Duke JM, Messer KD (2013) Adverse selection in reverse auctions for ecosystem services. Land Econ 89:387-412

Atkinson S, Tietenberg T (1987) Economic implications of emissions trading rules for local and regional pollutants. Can J Econ 20:370-386

Banerjee S, Kwasnica A, Shortle J (2012) Agglomeration bonus in small and large local networks: a laboratory examination of spatial coordination. Ecol Econ 84:142-152

Banerjee S, Secchi S, Fargione J, Polasky S, Kraft S (2013) How to sell ecosystem services: a guide for designing new markets. Front Ecol Environ 11:297-304 
Banerjee S, de Vries FP, Hanley N, van Soest DP (2014) The impact of information provision on agglomeration bonus performance: an experimental study on local networks. Am J Agric Econ 96:1009-1029

Banerjee S, Kwasnica A, Shortle J (2015) Information and auction performance: a laboratory study of conservation auctions for spatially contiguous land management. Environ Res Econ 61:409-431

Baumol WJ, Oates WE (1971) The use of standards and prices for the protection of the environment. Swed J Econ 73:42-54

Baumol WJ (1972) On taxation and the control of externalities. Am Econ Rev 62:307-322

Baumol WJ, Oates WE (1988) The theory of environmental policy, 2nd edn. Cambridge University Press, Cambridge

Burtraw D, Palmer K, Kahn D (2010) A symmetric safety valve. Energy Policy 38:4921-4932

Cabe R, Herriges JA (1992) The regulation of non-point source pollution under imperfect and asymmetric information. J Environ Econ Manag 22:134-146

Calel R (2012) Improving cost-efficiency of conservation auctions with joint bidding. J Environ Econ Policy 1:128-145

Cason TN, Gangadharan L (2004) Auction design for voluntary conservation programs. Am J Agric Econ $86: 1211-1217$

Cason TN, Gangadharan L (2005) A laboratory comparison of uniform and discriminative price auctions for reducing non-point source pollution. Land Econ 81:51-70

Cason TN, Gangadharan L (2006) Emissions variability in tradable permit markets with imperfect enforcement and banking. J Econ Behav Org 61:199-216

Cason TN, Gangadharan L, Duke C (2003) A laboratory study of auctions for reducing non-point source pollution. J Environ Econ Manag 46:446-471

Coase R (1960) The problem of social cost. J Law Econ 3:1-44

Common M (1977) A note on the use of taxes to control pollution. Scand J Econ 79:345-349

Crocker T (1966) Structuring of atmospheric pollution control systems. In: Wolozin H (ed) The economics of air pollution. W.W. Norton, New York

Cropper ML, Oates WE (1992) Environmental economics: a survey. J Econ Lit 30:675-740

Dales JH (1968) Pollution, property and prices. University of Toronto Press, Toronto

Derissen S, Quaas MF (2013) Combining performance-based and action-based payments to provide environmental goods under uncertainty. Ecol Econ 85:77-84

Ehmke M, Jones-Ritten C, Shogren J, Panchalingam T (2015) Integrating ecological and economic considerations for pollinator habitat policy. Choices 30(2):1-7

Ellerman AD, Joskow P, Harrison D (2003) Emissions trading in the US: experience, lessons, and considerations for greenhouse gases. Pew Center on Global Climate Change, Washington, DC

Engel S, Pagiola S, Wunder S (2008) Designing payments for environmental services in theory and practice: an overview of the issues. Ecol Econ 65:663-674

European Environment Agency (EEA) (2014) Resource-efficient green economy and EU policies. European Environment Agency, Copenhagen

Fell H, Morgenstern RD, Palmer KL (2012) Soft and hard price collars in a cap-and-trade system: a comparative analysis. J Environ Econ Manag 64:183-198

Ferraro PJ (2008) Asymmetric information and contract design for payments for environmental services. Ecol Econ 65:810-821

Fisher-Vanden K, Olmstead S (2013) Moving pollution trading from air to water: potential, problems, and prognosis. J Econ Perspect 27:147-172

Fooks JR, Messer KD, Duke JM (2015) Dynamic entry, reverse auctions, and the purchase of environmental services. Land Econ 91:57-75

Fowlie M, Muller N (2013) Market-based emissions regulation when damages vary across sources: What are the gains from differentiation? NBER Working Paper 18801

Fraser R (2009) Land heterogeneity, agricultural income foregone and environmental benefits. J Agric Econ 60:190-201

Glebe TW (2013) Conservation auctions: Should information about environmental benefits be made public? Am J Agric Econ 95:590-605

Gómez-Baggethun E, de Groot R, Lomas PL, Montes C (2010) The history of ecosystem services in economic theory and practice: from early notions to markets and payment scheme. Ecol Econ 69:1209-1218

Goulder LH, Schein AR (2013) Carbon taxes versus cap and trade: a critical review. Clim Change Econ 4:28

Hajkowicz S, Higgins A, Williams K, Faith DP, Burton M (2007) Optimisation and the selection of conservation contracts. Aust J Agric Res Econ 51:39-56

Hanley N, Shogren JF, White B (2006) Environmental economics in theory and practice. Palgrave MacMillan, London 
Hanley N, Banerjee S, Lennox GD, Armsworth PR (2012) How should we incentivize private landowners to 'produce' more biodiversity? Oxf Rev Econ Policy 28:93-113

Horan RD, Shortle JS, Abler DG (1998) Ambient taxes when polluters have multiple choices. J Environ Econ Manag 36:186-199

Jack BK, Kousky C, Sims KRE (2008) Designing payments for ecosystem services: lessons from previous experience with incentive-based mechanisms. Proc Nat Acad Sci 105:9465-9470

Jones LR, Vossler CA (2014) Experimental tests of water quality trading markets. J Environ Econ Manag 68:449-462

Karp L, Livernois J (1994) Using automatic tax changes to control pollution emissions. J Environ Econ Manag 27:38-48

Kawasaki K, Fujie T, Koito K, Inoue N, Sasaki H (2012) Conservation auctions and compliance: theory and evidence from laboratory experiments. Environ Res Econ 52:157-179

Latacz-Lohmann U, Van der Hamsvoort CPCM (1997) Auctioning conservation contracts: a theoretical analysis and an application. Am J Agric Econ 79:407-418

Latacz-Lohmann U, Van der Hamsvoort CPCM (1998) Auctions as a means of creating a market for public goods from agriculture. J Agric Econ 49:334-345

Millennium Ecosystem Assessment (MEA) (2005) Ecosystems and human well-being: synthesis. Island Press, Washington, DC

Miteva DA, Pattanayak SK, Ferraro PJ (2012) Evaluation of biodiversity policy instruments. Oxf Rev Econ Policy 28:69-92

Montgomery W (1972) Markets in licences and efficient pollution control programs. J Econ Theory 5:395-418

Muller NZ, Mendelsohn R (2009) Efficient pollution regulation: getting the prices right. Am Econ Rev 99:1714-1739

Murray BC, Newell RG, Pizer WA (2009) Balancing cost and emissions certainty: an allowance reserve for cap-and-trade. Rev Environ Econ Policy 3:84-103

OECD (2010a) Paying for biodiversity: enhancing the cost-effectiveness of payments for ecosystem services. Organisation for Economic Co-operation and Development, Paris

OECD (2010b) Taxation. Organisation for Economic Co-operation and Development, Innovation and the Environment, Paris

Parkhurst GM, Shogren JF, Bastian C, Kivi P, Donner J, Smith RBW (2002) Agglomeration bonus: an incentive mechanism to reunite fragmented habitat for biodiversity conservation. Ecol Econ 41:305-328

Parkhurst GM, Shogren JF (2007) Spatial incentives to coordinate contiguous habitat. Ecol Econ 64:344-355

Parkhurst GM, Shogren JS, Crocker T (2015) Tradable set-aside requirements (TSARs): conserving spatially dependent environmental amenities, Environmental and Resource Economics (in press)

Pearce DW (2002) An intellectual history of environmental economics. Annu Rev Energy Environ 27:57-81

Perkis DF, Cason TN, Tyner WE (2015) An experimental investigation of hard and soft price ceilings in emissions permit markets, Environmental and Resource Economics (in press)

Polasky S, Lewis DL, Plantinga AJ, Nelson E (2014) Implementing the optimal provision of ecosystem services. Proc Nat Acad Sci 111:6248-6253

Ribaudo MO, Heimlich R, Peters M (2005) Nitrogen sources and Gulf hypoxia: potential for environmental credit trading. Ecol Econ 52:159-168

Reeson AF, Rodriguez LC, Whitten SM, Williams K, Nolles K, Windle J, Rolfe J (2011) Adapting auctions for the provision of ecosystem services at the landscape scale. Ecol Econ 70:1621-1627

Rolfe J, Windle J, McCosker J (2009) Testing and implementing the use of multiple bidding iterations in conservation auctions: a case study application. Can J Agric Econ 57:287-303

Rolfe J, Windle J (2011) Using auction mechanisms to reveal costs for water quality improvements in great barrier reef catchments in Australia. Agric Water Manag 98:493-501

Schilizzi S, Latacz-Lohman U (2007) Assessing the performance of conservation auctions: an experimental study. Land Econ 83:497-515

Segerson K (1988) Uncertainty and incentives for nonpoint pollution control. J Environ Econ Manag 15:87-98

Shortle JS, Horan RD (2008) The economics of water quality trading. Int Rev Environ Res Econ 2:101-133

Shortle JS, Horan RD, Abler DG (1998) Research issues in nonpoint pollution control. Environ Res Econ 11:571-585

Smulders S, Vollebergh HRJ (2015) Choosing corrective taxes in the presence of administration cost, paper presented at EAERE conference, Helsinki. www.eaere2015.org. Accessed 10 Aug 2015

Stephenson K, Shabman L (2011) Rhetoric and reality of water quality trading and the potential for market-like reform. J Am Water Res Assoc 47:15-28

Stranlund JK, Murphy JJ, Spraggon JM (2014) Price controls and banking in emissions trading. J Environ Econ Manag 68:71-86 
Suter JF, Vossler CA (2014) Towards an understanding of the performance of ambient tax mechanisms in the field: evidence from upstate New York dairy farmers. Am J Agric Econ 96:92-107

Suter JF, Vossler CA, Poe GL, Segerson K (2008) Experiments on damage-based ambient taxes for nonpoint source polluters. Am J Agric Econ 90:86-102

Tietenberg TH (1974) On taxation and the control of externalities: comment. Am Econ Rev 64:462-466

Vossler CA, Suter JF, Poe GL (2013) Experimental evidence on dynamic pollution tax policies. J Econ Behav Org 93:101-115

Walker M, Storey D (1977) The 'standards and prices' approach to pollution control: problems of iteration. Scand J Econ 79:99-109

Weber TA, Neuhoff K (2010) Carbon markets and technological innovation. J Environ Econ Manag 60(2):115132

White B, Sadler R (2012) Optimal conservation investment for a biodiversity rich agricultural landscape. Aust J Agric Res Econ 56:1-21

White B, Hanley N (2015) Should we pay for ecosystem service outputs, actions or both? Environ Res Econ, forthcoming

Whitten SM, Reeson A, Windle J, Rolfe J (2013) Designing conservation tenders to support landholder participation: a framework and case study assessment. Ecosyst Serv 6:82-92

Williams KJ, Reeson AF, Drielsma MJ, Love J (2012) Optimised whole-landscape ecological metrics for effective delivery of connectivity-focused conservation incentive payments. Ecol Econ 81:48-59

Windle J, Rolfe J, McCosker J, Lingard A (2009) A conservation auction for landscape linkage in the southern Desert Uplands, Queensland. Rangel J 31:127-135

Wood P, Jotzo F (2011) Price floors for emissions trading. Energy Policy 39:1746-1753

Wünscher T, Engel S, Wunder S (2008) Spatial targeting of payments for environmental services: a tool for boosting conservation benefits. Ecol Econ 65:822-833 